\title{
A Comparative Study of Work Life Balance in Engineering Consultancies in NCR during COVID-19
}

\author{
$\underline{\text { Author Details }}$ \\ Dr. Kokila Saxena, \\ Assistant Professor, \\ Department of Management Studies, \\ JSS Academy of Technical Education, Noida \\ Mail id.: kokilasaxena.dms@jssaten.ac.in \\ M.No. 9868633384 \\ Ms. Shalini Prakash \\ Research Scholar, \\ Dr. APJ Abdul Kalam Technical University, Lucknow
}




\title{
A Comparative Study of Work Life Balance in Engineering Consultancies in NCR during COVID-19
}

\begin{abstract}
$\underline{\text { Abstract }}$
The paper determines the level of work life balance (WLB) while work from home and while attending the office regularly. The participants were same and they have to rate the Work Life Balance assuming themselves in both the situations. The two groups compared were male employees and female employees. The participants were taken randomly from four engineering consultancies in NCR (Jacobs Engineering, Tractebel Engineering, Bechtel India Pvt. Ltd. and Ercom Engineers Pvt. 1td.). 124 completed responses found to be completed. Further the study compares the mean values of Work Life Balance while work from home and regular office among male and female employees. The results reveal that the employees can maintain the WLB level well while work from home. The hypothesis testing results show that there is no significant difference among the male and female employees in the level of Work Life Balance while work from home and regular office.
\end{abstract}

KEY WORDS: Work life balance, work from home, Competitive advantage, Lockdown, Electronic medium, diversified workforce, freelancers

\section{$\underline{\text { Introduction }}$}

The outbreak of pandemic of COVID-19 led to the situation of lockdown in the country. Indian industries faced immediate and total lockdown starting from March 2020 and later on companies started coming on the tracks by letting their employees work from home. However, work from home cannot be executed in all the sectors extensively in the service sector which renders tangible services like hospitality, medical, banks and home delivery services. On the other hand, work from home proved to be a good alternative for those who can deliver their services to their clients through electronic medium like IT services, customer care and consultancy services. 
The consultancy sector segregated on the basis of academic disciplines is: management consultancies, IT consultancies, engineering consultancies, advertising consultancies and legal consultancies and others. Among the above, the management consultancies comprises of more broader division like HRM, financial, marketing, PR, strategic and operations management consultancies. Engineering consultancies in India have created milestones through their quality services. The Indian workforce in the field of engineering has shown a competitive advantage to work within MNC's and for foreign clients in domestic and international projects. They deliver quality engineering services to various industrial segments like power plants, oil and gas, process plants (pharmaceutical companies, chemical companies, water treatment plants and food industries). The engineering consultancies hands outs their aids in the disciplines of civil, mechanical and electrical engineering. They offer project management, architecture and infrastructure planning, engineering designing, procurement, construction and installation facilities.

India has been a country of diversified workforce. Most engineering consultancies in National Capital Region (NCR) which is said to be most developed and the core of small scale to MNC's generating highest percentage of jobs with 2.6 lakhs in Delhi followed by Bangalore with 1.5 lakhs during the last quarter of 2016 as depicted by the Associated Chambers of Commerce and Industry of India (ASSOCHAM). The engineering consultancies found to have $40-60$ ratios of female and male employees consecutively. Although the international companies in India are adapting and implementing their policies in such a way so as to ease their employees to work more efficiently without stress maintaining their professional and personal life both but still sometimes there are issues of work life balance within the employees regardless of gender differences.

\section{$\underline{\text { Literature Review }}$}

\section{Work from Home (WFH)}

The concept of work from home is however not new but the worldwide spread of COVID-19 has made it usual and looks like as if it would be sustained this year in India. The recent version of work from home can be seen as a characteristic in the freelancers. Some freelancers work independently without a regular salary and mostly found to work from home. When we indulge 
in the work from home topic in the context of regular pay basis in the companies, its more meaning full to talk about work from home. In an organization when employees work from home it means that they are virtually connected to all the other employees in the company. On the other hand, the companies also constitute to make work from home (WFH) more comfortable for its employees. They are regularly issuing the information about being more productive while WFH and making updates in their IT system to make the communication better. WFH has been found to have mutually beneficial situation for employees and employers both and creating a work life balance at the same time (Madsen, 2003). Previous studies have revealed out that there is a positive relationship between the productivity and performance of the employee and work from home (Bailyn 1988; Olson 1989; DuBrin 1991; Belanger 1999). Many past researches have enunciated the advantages and hindrances of WFH (Baruch 2000; Gajendran and Harrison 2007) and had examined the effect of WFH on the performance of the employees (Sullivan and Lewis 2001; Hill, Ferris and Martinson 2003; Golden, Veiga and Simsek 2006). DuBrin, 1991 found that work from home accelerates the efficiency and boosts the overall productivity and performance of the team members.

However the scene of work from home in India is not so common but, later on it made the companies to realize they it is yielding an advantageous situation for them. The companies do not now have to spend on high costs on the conveyance facilities to their employees. The companies which were providing mess and cafeteria (lunch) now do not need to spend on it. The cost of stationery or other paraphernalia with the printing costs which is mostly high in engineering consultancies has been totally vanished. The cost incurred on some other blue collared employees like the office boys and cleanliness staffs have been lowered though not fully absent. The highest cost which the engineering companies incur on the overtime of their employees is not there now. The engineering consultancies offer the salary to its employees on the basis of working hours. The employees are working from home and the priority is to complete the daily tasks. Although they have the same timings as in regular office but sometimes the employees have to work for more hours so that they can complete, and the companies still now do not have any payments for the extra time the employees are working as overtime. 


\section{Work Life Balance (WLB)}

Work life balance is a concept of maintaining equilibrium between the personal and the professional life. The employees some times are caught into so much work that they do not have spare time neither for their family responsibilities nor for themselves. The imbalance between work and personal life influences the mental well being of the employees which can lead to low performance levels or low quality performance. Maintaining the work life balance is found to be a big issue for the women employees in a country like India as the women are expected to do all household work also after the office. However, sometimes it helps them to be in joint family so that the other family responsibilities like: looking after children at home, sending them to school and bringing them back home, feeding etc are borne by the elders or grandparents.

The concept of work life balance has been broadening. Some researchers have explained the work life balance on the basis of different bit part played by an individual in his life (Greenhaus, Collins \& Shaw, 2003). In due course of time it work life balance extended to the employees self satisfaction also. Mental self satisfaction and spare time to distress contributes to work life balance (Kirchmeyer, 2000). Work life balance induces high and consistent performance of the employees and gives a break from the routine work to the employees promoting mental health (Lockwood, 2003). Work life balance has been improved during this COVID-19 situation for the reason that employees are working from home. Work from home enables the employees to work in alternative schedule hours. They are not confined to strict office timings. They can also fulfill their family responsibilities and spend time with their family. Apart from this they also have time for themselves to distress themselves.

\section{Objectives}

1. To identify the level of work life balance of the employees while work from home and during regular office.

2. To identify whether there is difference in the level of work life balance between the men and women employees while work from home.

3. To identify whether there is difference in the level of work life balance between the men and women employees while regular office. 


\section{Hypothesis}

$\mathbf{H}_{\mathbf{1}}$ : There is a significant difference between the mean values of WLB while work from home among male and female employees.

$\mathbf{H}_{\mathbf{0}}$ : There is no significant difference between the mean values of WLB while work from home among male and female employees.

$\mathbf{H}_{2}$ : There is a significant difference between the mean values of WLB while attending regular office among male and female employees.

$\mathbf{H}_{\mathbf{0}}$ : There is no significant difference between the mean values of WLB while attending regular office among male and female employees.

\section{Data Collection and Participants}

150 questionnaires were distributed online to the random employees of the 4 engineering consultancies in the NCR region named: Jacobs Engineering, Tractebel Engineering, Bechtel India Pvt. Ltd. and Ercom Engineers Pvt. ltd . 124 completed responses came back.

\section{$\underline{\text { Research Methodology }}$}

A questionnaire was plotted with the help of literature review to measure WLB. The questionnaire was based on the components of WLB like: time for self, happiness, family responsibilities, distress time, balancing work and family, leisure time and working hours both at the time when employees were attending the office regularly and while they work from home. The level of WLB while work from home and while attending the regular office was measured by just taking out the mean values for each employee against each question and then compared. The hypothesis testing was done with the help of $\mathrm{t}$ - test. The figures below (1a and $1 \mathrm{~b}$ ) meet the assumption for $\mathrm{t}$ - test since they both are showing a normal distribution. 


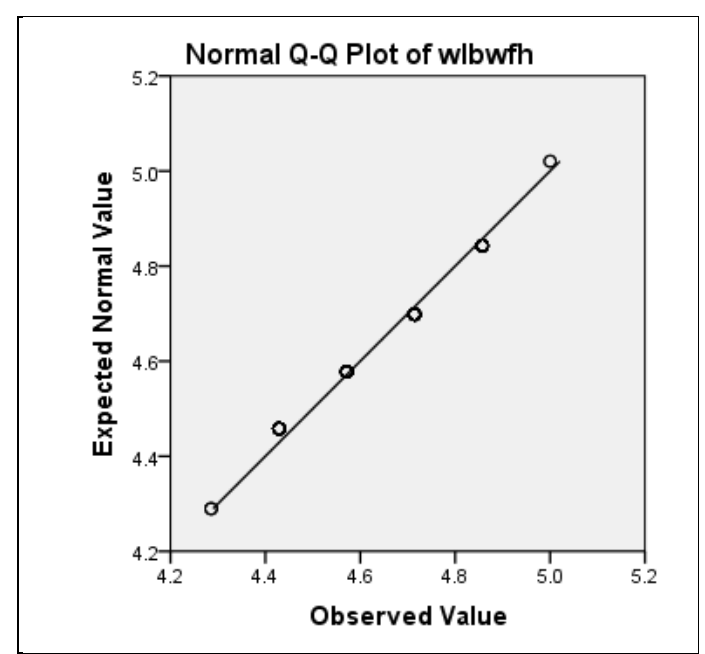

Figure: 1a

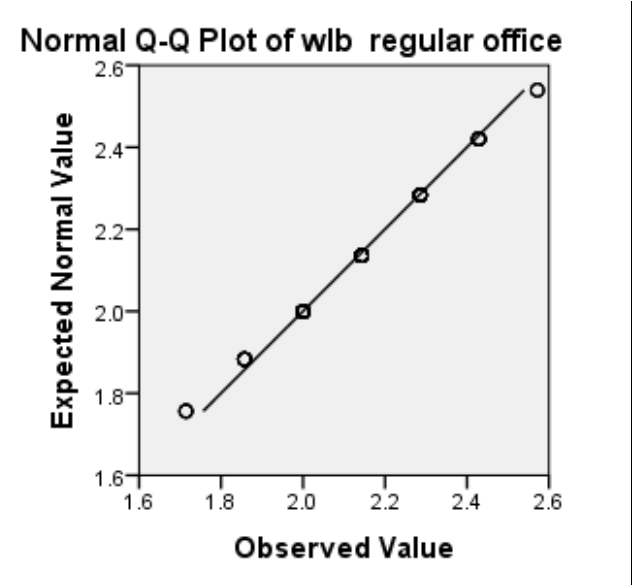

Figure: 1b

\section{Results and Findings}

Table 1, 2 and 3 shows the descriptive statistics of the data collected from the 4 engineering consultancies from the NCR region.

\begin{tabular}{|c|c|c|c|c|c|}
\hline \multicolumn{6}{|c|}{ Gender } \\
\hline & & Frequency & Percent & Valid Percent & $\begin{array}{c}\text { Cumulative } \\
\text { Percent }\end{array}$ \\
\hline \multirow{2}{*}{ Valid } & Male & 67 & 54.0 & 54.0 & 54.0 \\
\hline & Female & 57 & 46.0 & 46.0 & 100.0 \\
\hline
\end{tabular}




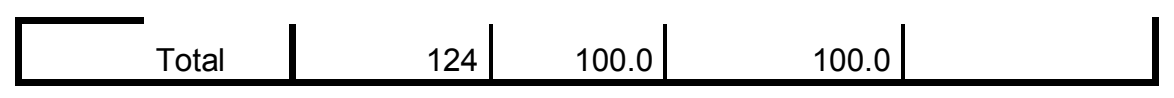

Table: 1

\begin{tabular}{|c|c|c|c|c|c|}
\hline \multicolumn{6}{|c|}{ Marital status } \\
\hline & & Frequency & Percent & Valid Percent & $\begin{array}{c}\text { Cumulative } \\
\text { Percent }\end{array}$ \\
\hline \multirow{3}{*}{ Valid } & Married & 67 & 54.0 & 54.0 & 54.0 \\
\hline & not married & 57 & 46.0 & 46.0 & 100.0 \\
\hline & Total & 124 & 100.0 & 100.0 & \\
\hline
\end{tabular}

Table: 2

\section{Descriptive Statistics}

\begin{tabular}{|l|r|r|r|}
\hline & \multicolumn{1}{|c|}{$\mathrm{N}$} & \multicolumn{1}{|c|}{ Mean } & Std. Deviation \\
\hline Wlbwfh & 124 & 4.6440 & .15932 \\
wlb regular office & 124 & 2.1302 & .18399 \\
Valid N (listwise) & 124 & & \\
\hline
\end{tabular}

Table: 3

Table 3, above shows the total mean value of WLB while work from home (WFH) as 4.6440 and WLB while the employees were attending regular office as 2.1302 . The analysis indicates that WLB among the employees is more when they work from home than that of attending the office regularly.

$\mathbf{H}_{\mathbf{1}}$ : There is a significant difference between the mean values of WLB while work from home among male and female employees.

\begin{tabular}{|r|l|r|r|r|r|}
\hline \multirow{3}{*}{ wlbwfh } & Gender & $\mathrm{N}$ & \multicolumn{1}{c|}{ Mean } & Std. Deviation & Std. Error Mean \\
\hline \multirow{3}{*}{ Male } & 67 & 4.6439 & .14149 & .01729 \\
& Female & 57 & 4.6441 & .17933 & .02375 \\
\hline
\end{tabular}

Table: 4 
Independent Samples Test

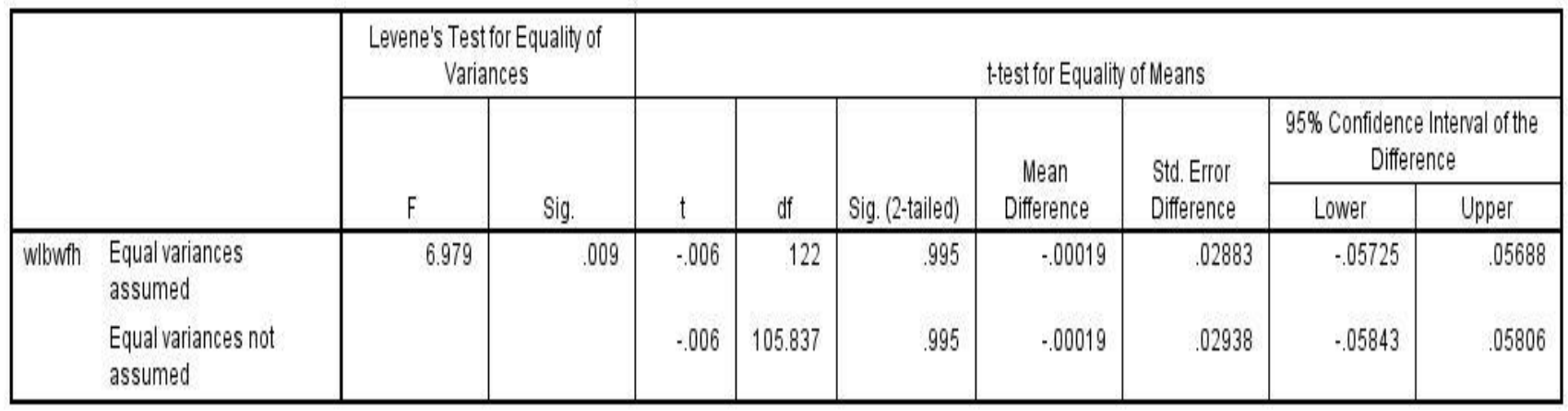

Table: 5

Table 5 shows the independent $t$ test for hypothesis $H_{1}$. The results of Levene's test, $F(122)=$ $6.97, \mathrm{p}=.009$, here $\mathrm{p}$ value is less than the significant value .05 , indicating that the variances of the two populations are not assumed to be approximately equal. The results of the independent $t$ test were not significant, $\mathrm{t}(122)=-.006, \mathrm{p}=.99$, indicating that there is no significant difference between the mean values of WLB while work from home of males ( $\mathrm{M}=4.643, \mathrm{SD}=.141, \mathrm{~N}=$ 67 ) and the mean values of WLB while work from home of females $(\mathrm{M}=4.644, \mathrm{SD}=.179, \mathrm{~N}=$ 57). So, the researcher failed to reject the null hypothesis.

$\mathbf{H}_{2}$ : There is a significant difference between the mean values of WLB while attending regular office among male and female employees.

\section{Group Statistics}

\begin{tabular}{|lll|r|r|r|r|}
\hline & Gender & \multicolumn{1}{|c|}{$\mathrm{N}$} & \multicolumn{1}{c|}{ Mean } & Std. Deviation & Std. Error Mean \\
\hline \multirow{3}{*}{ wlb regular office } & Male & 67 & 2.1471 & .18770 & .02293 \\
& Female & 57 & 2.1103 & .17912 & .02372 \\
\hline
\end{tabular}

Table: 6 
Independent Samples Test

\begin{tabular}{|c|c|c|c|c|c|c|c|c|c|c|}
\hline & & \multicolumn{2}{|c|}{$\begin{array}{c}\text { Levene's Test for Equality of } \\
\text { Variances }\end{array}$} & \multicolumn{7}{|c|}{ t-testfor Equality of Means } \\
\hline & & \multirow[b]{2}{*}{$F$} & \multirow[b]{2}{*}{ Sig. } & \multirow[b]{2}{*}{$t$} & \multirow[b]{2}{*}{ df } & \multirow[b]{2}{*}{ Sig. (2-tailed) } & \multirow{2}{*}{$\begin{array}{c}\text { Mean } \\
\text { Difference } \\
\end{array}$} & \multirow{2}{*}{$\begin{array}{l}\text { Std. Error } \\
\text { Difference }\end{array}$} & \multicolumn{2}{|c|}{$\begin{array}{c}95 \% \text { Confidence Interval of the } \\
\text { Difference }\end{array}$} \\
\hline & & & & & & & & & Lower & Upper \\
\hline wlb regular office & $\begin{array}{l}\text { Equal variances } \\
\text { assumed }\end{array}$ & .027 & .871 & 1.112 & 122 & .268 & .03685 & .03312 & .02872 & .10241 \\
\hline & $\begin{array}{l}\text { Equal variances not } \\
\text { assumed }\end{array}$ & & & 1.117 & 120.371 & .266 & .03685 & .03300 & .02848 & .10217 \\
\hline
\end{tabular}

Table: 7

Table 7 shows the independent $\mathrm{t}$ test for hypothesis $\mathrm{H}_{2}$. The results of Levene's test, $\mathrm{F}(122)=$ $6.97, p=.871$, here $p$ value is more than the significant value .05 , indicating that the variances of the two populations are not assumed to be approximately equal. The results of the independent $t$ test were not significant, $\mathrm{t}(122)=1.112, \mathrm{p}=.268$, indicating that there is no significant difference between the mean values of WLB while work from home of males $(\mathrm{M}=2.147, \mathrm{SD}=$ $.187, \mathrm{~N}=67)$ and the mean values of WLB while work from home of females $(\mathrm{M}=2.110, \mathrm{SD}=$ $.179, \mathrm{~N}=57$ ). So, the researcher failed to reject the null hypothesis.

\section{Conclusion}

The mean values of WLB while work from home and while regular office with 4.644 and 2.130 respectively concludes that the employees are able to maintain the work life balance better while they work from home rather than regular office. Regardless of gender the employees get more time to distress themselves, be happy and fulfill family responsibilities when they work from home.

The hypothesis testing results reveals that there is no significant difference between the mean values of males and females of WLB while they work from or when they attended the office regularly. All the employees despite of gender differences are more convenient to work from home rather than attending the office regularly. 


\section{References:}

1. Bailyn, Lotte. 1988. Freeing work from the constraints of location and time. New Technology, Work and Employment 3(2): 143-152.

2. Baruch, Yehuda. 2000. Teleworking: Benefits and pitfalls as perceived by professionals and managers. New Technology, Work and Employment 15(1): 34-49.

3. Belanger, France. 1999. Workers' propensity to telecommute: An empirical study. Information and Management 35(3): 139-153.

4. DuBrin, Andrew J.1991. Comparison of the job satisfaction and productivity of telecommuters versus in-house employees: A research note on work in progress. Psychological Reports 68(3c): 1223-1234.

5. Gajendran, Ravi S., and David A. Harrison. 2007. The good, the bad, and the unknown about telecommuting: Meta-analysis of psychological mediators and individual consequences. Journal of Applied Psychology 92(6): 1524-1541.

6. Golden, Timothy D., John F. Veiga, and Zeki Simsek. 2006. Telecommuting's differential impact on work-family conflict: Is there no place like home? Journal of Applied Psychology 91(6): 1340- 1350

7. Greenhaus JH, Collins KM and Shaw JD (2003) The relation between work-family balance and quality of life. Journal of Vocational Behavior 63: 510-531.

8. Hill, E. Jeffrey, Maria Ferris, and Vjollca Märtinson. 2003. Does it matter where you work? A comparison of how three work venues (traditional office, virtual office, and home office) influence aspects of work and personal/family life. Journal of Vocational Behavior 63(2): 220-241.

9. Kirchmeyer C (2000) Work-life initiatives: Greed or benevolence regarding workers' time. In CL Cooper and DM Rousseau (Eds) Trends in Organisational Behavior, 7:7993. Chichester: John Wiley \& Sons.

10. Lockwood, N. R. (2003). Work/Life Balance-Challenges and Solutions. Alexandria,USA: Society for Human Resource Management (SHRM).

11. Madsen, S. R. (2003), "The effects of home-based teleworking on work-family conflict", Human Resource Development Quarterly, Vol. 14 No.1, pp. 35-58.

12. Olson; Margrethe H.. 1989. Work at home for computer professionals: Current attitudes and future prospects. ACM Transactions on Information Systems (TOIS) 7(4): 317-338.

13. Sullivan, Cath, and Suzan Lewis. 2001. Home-based telework, gender, and the synchronization of work and family: Perspectives of teleworkers and their co-residents. Gender, Work and Organization 8(2): 123-145. 